\author{
水酸アパタイトの着色現象（第 2 報） \\ 石川 剛 \\ ペンタックス(株)ライフケア事業本部ニューセラミックス事業部開発部，174-8639 東京都板橋区前野町 2-36-9
}

\title{
Coloring Phenomenon of Hydroxyapatite (Part 2)
}

\author{
Tsuyoshi ISHIKAWA \\ Research \& Development Department, New Ceramics Division, Life Care Business Headquarters, PENTAX Corporation, \\ 2-36-9, Maeno-cho, Itabashi-ku, Tokyo 174-8639
}

\begin{abstract}
The hydroxapatite coloring phenomenon after high-temperature firing was caused by the kinds of atmosphere gasses and the pressure. Especially the influence of oxygen on the coloring was strong. $X$-ray diffraction measurement showed that the hydroxapatite coloring phenomenon corresponded to the crystal phase transition of hydroxapatite. The crystal system of white and red hydroxapatite was monoclinic and reddish-brown hydroxapatite was hexagonal. From the measurement of the spectrophotometer, red hydroxapatite had an absorption band near $537 \mathrm{~nm}$. This absorption band was considered to be due to the color center.
\end{abstract}

[Received January 16, 2004; Accepted June 24, 2004]

Key-words : Hydroxapatite, Firing, Coloring phenomenon, Monoclinic, Hexagonal, Color center

\section{1. はじめに}

水酸アパタイト (HAp) は, 生体活性の優れた材料として広 く認知されているばかりでなく, 電子材料や環境浄化材料など として幅広い応用が期待されている.このような応用を検討し たり医療材料として使用する際に，その基本物性を把握してお くことが重要である.HApの物性については，すでに数多く の研究報告や解説 ${ }^{1)}$ 4) があるが, HAp の燒成による着色現象 については, いくつかの報告1),2)があるものの系統的に検討し た研究は見当たらない。著者らは前報 ${ }^{5}$ において, 湿式合成し たHAp を焼成する際に抢こる着色現象について，その種類々 発生する合成条件を明らかにし, 更に着色現象が焼成時の雾囲 気である大気中の酸素, 窒素によって引き起こされる可能性を 示した。本報では, 雾囲気炉を用いて, 焼成時に酸素, 窒素を 雾囲気とした場合とアルゴンを雾囲気にした場合の結果を比較 し, 酸素, 窒素が HApの着色に与える影響を調べた。その結 果を基に，焼成雾囲気，焼成方法と着色との関係を明らかにし た，更に，着色した HAp の特性を調べ，着色の発生原因を検 討した.

\section{2. 試料と実験方法}

\section{1 測定試料}

\subsubsection{HAp の合成}

高純度の水酸化カルシウムとリン酸を出発原料として, 化学 式(1)に示す湿式の反応で生成したスラリーを，噴霧乾燥機に より粒径 $18 \mu \mathrm{m}$ 程度の顆粒に造粒し, 乾燥して HAp を合成し

た. 数回の合成を行った試料の中から大気中 $1200^{\circ} \mathrm{C} の$ 焼成によ り, 赤色 $(\mathrm{CIE}$ 色度 $(X, Y)$ 図上の $(0.512,0.361))$ に着色 したHAp を選んで実験に用いた ${ }^{5)}$.

$$
10 \mathrm{Ca}(\mathrm{OH})_{2}+6 \mathrm{H}_{3} \mathrm{PO}_{4} \longrightarrow \mathrm{Ca}_{10}\left(\mathrm{PO}_{4}\right)_{6}(\mathrm{OH})_{2}+18 \mathrm{H}_{2} \mathrm{O}
$$

\subsection{2 着色測定用 HAp 焼結体の作製}

着色の測定には，前報 ${ }^{5)} に$ 示したように焼結体を用いること が顆粒に比べ着色を観察しやすい。 そこで, 以下のように焼結
体を作製した２.1.1項で準備した HAp 顆粒を純水 6 に対して 顆粒 5 の重量比で混練した後, 型に入れ乾燥した. この乾燥成 形体を密閉式高温雾囲気炬に入れ, 純度 $99.9 \%$ の酸素, 窒素, アルゴンの各雾囲気中で, $1200^{\circ} \mathrm{C}, 2 \mathrm{~h}$ 保持の条件で焼成し た. 焼成方法として, 炉内に一定量の雲囲気ガスを入れた後, 密閉した状態で焼成する方法（減圧焼成）と雾囲気ガスを流し 続ける焼成方法（常圧燒成）との二つの方法を用いた. 燒結し た試料の厚さ (光路長) は $3 \mathrm{~mm}$ にダイヤモンドディスクで加 工した.

\subsection{3 キャラクタリゼーション用試料の作製}

作製した白色及び着色焼結体（三種類）と比較用のち密体 （一種類）の作製条件を表 1 に示す. 白色焼結体（White type (a)）は，2.1.2項でアルゴン雾囲気, 常圧焼成によって作製し た焼結体である.赤色焼結体 (Red type (b)) は, この白色燒 結体を酸素雾囲気中で，再度常圧焼成したものである。このと き, 焼結体試料は厚さ $4 \mathrm{~mm}$ 以下にし, 焼成時に試料が酸素に 暴露しやすいように，アルミナブロックを使い試料の下に空間 を作るようにした。豆色焼結体 (Reddish-brown type (c)) は, 白色燒結体を酸素雾囲気中で粒径 $80 \mu \mathrm{m}$ の焼結した HAp 顆粒に埋入して, 再度常圧焼成して作製したものである. 比較 試料のち密体 (d) は, 粒径 $18 \mu \mathrm{m}$ 程度の HAp 顆粒を $196 \mathrm{MPa}$ の 静水圧プレスで円柱ペレットに成形し, 大気中 $1200^{\circ} \mathrm{C}, 2 \mathrm{~h}$ 保 持で焼結させ作製した. ち密体の相対密度は, アルキメデス法 による測定で $99 \%$ であった。

Table 1. Coloring HAp Samples for Characterization

\begin{tabular}{llll}
\hline & \multicolumn{3}{l}{ Firing conditions } \\
\cline { 2 - 4 } Sample: & $\begin{array}{l}\text { Temperature } \\
/ \mathrm{C}\end{array}$ & Atmosphere & Remark \\
\hline White type (a) & 1200 & $\mathrm{~A} \mathrm{r}$ & \\
Red type: (b) & 1200 & $\mathrm{O}_{2}$ & The sintered block is re-fired. \\
Re:ddish-brown type (c) & 1200 & $\mathrm{O}_{2}$ & $\begin{array}{l}\text { The sintered block is re-fired } \\
\text { in sintered Ho granule:s. }\end{array}$ \\
High density type (d) & 1200 & Air & \\
\hline
\end{tabular}




\section{2 実験方法}

\subsection{1 実験 1（着色 HAp における焼成雾囲気と焼成方法と の関係)}

2.1.2項で準備した HAp 成形体試料を容積 $100 \mathrm{dm}^{3}$ の密閉式 雾囲気炉内に入れ, ロータリーポンプで炉内を減圧後, 各雾囲 気ガス (酸素, 窒素, アルゴン) を塩化カルシウムの乾燥管を 通し炉内に送り込んだ。減圧焼成では, 炬内圧力が常温で $0.100,0.075,0.050,0.025,0.013,0.006 \mathrm{MPa}$ のどれかになるよ うに設定した後, 炉を密閉し焼成を行った。 焼成中は, 温度上 昇により密閉炉内の圧力上昇がおこるが，圧力の調整は行わな かった. 常圧焼成では, 炉内を各雾囲気ガスで満たした後, そ のガスを一定の流量で流した状態で焼成を行った．このとき， 炉内圧力は $0.115 \mathrm{MPa}$ であった。得た焼結体の着色は, $85 \mathrm{~W}$ のハロゲンランプ光をファイバーで焼結体背面から照射し, 色 彩色差計（ミノルタ製，CS-100）を用いて測定した。評価は, CIE 色度 $(X, Y)$ 図上で行った ${ }^{5)}$ 。その後, 着色した HAp 焼 結体を異なった䨌囲気中で, 再度常圧焼成を行い着色の雾囲気 依存性を調べた。

\subsection{2 実験 2（着色 HAp のキャラクタリゼーションと発生} 原因)

2.1.3 項で準備した三種類の着色焼結体とち密体の粉末 X 線 回折（XRD；リガク製，RINT2000を使用）及び赤外分光測定 を行った（フーリ工変換赤外吸収分光光度計 FT-IR ; パーキン エルマー製，1760X を使用)。粉末 XRD 測定により得られた (300)面, (002)面のデータから $a$ 軸, $c$ 軸方向の格子間隔を決 定し, この值とXRD パターンの特徵とを既知の文献と比較し 結晶系の同定をした. 着色発生メカニズムに関しては, 分光透 過率測定とESR スペクトルの観測によって検討した。分光透 過率測定には焼結体を厚さ $1 \mathrm{~mm}$ に加工し $250 \sim 800 \mathrm{~nm}$ の範囲 で行った（分光透過率計; 日立製作所製, U-4000を使用). ESR では質量約 $0.1 \mathrm{~g}$ の焼結体を用い $9.1 \mathrm{GHz}, 77 \mathrm{~K}$ の条件で観 測した (日本電子製, JES-FA を使用).$g$ 值は, マーカー法に より求めた.

\section{3. 結果と考察}

\section{1 着色 HAp における焼成雾囲気と焼成方法との関係}

図 1 は酸素, 窒素, アルゴンの各雾囲気中で焼成した焼結体 の着色を CIE 色度 $(X, Y)$ 図上に示した結果である。測定を 行った試料の場合は, CIE 色度 $(X, Y)$ 図で $(0.603,0.372)$ の着色を示すものと, $(0.460,0.401)$ から $(0.605,0.295)$ へ向 かって, 彩度が徐々に大きくなる方向へ延びる直線上に位置す るグループの二つに分かれることが分かった．代表的な焼結体 の写真を図 1 の1)〜 (4)に示した. (1)はもっとも彩度が小さく, CIE 色度 $(X, Y)$ 図で $(0.460,0.401)$ を示すので, 以下白色 焼結体 (a) と呼ぶ。(2)は, 白色焼結体と赤色焼結体のほぼ中間 の着色状態の焼結体である. (3)(4)は酸素雾囲気で常圧焼成した 焼結体である。(3) はもっとも彩度が大きく CIE 色度 $(X, Y)$ 図で $(0.605,0.295)$ を示すので赤色焼結体 (b) と呼ぶ. (4)の黒 い部分は CIE 色度 $(X, Y)$ 図で $(0.603,0.372)$ を示すので, 小豆色焼結体 (c) と名付けた。ここでは $(0.460,0.401)$ から $(0.605,0.295)$ の着色を示したグループの試料から検討を始め る、まず，酸素䨌囲気で焼成した試料がもっとも彩度が大きい グループを形成していることに注目をする。これは酸素雲囲気 下での焼成がもっとも強く HAp 焼結体を着色させることを示 している. 図 1 では密閉炉内で減圧焼成及び常圧焼成時の圧力 々着色の関係が分からない。そこで，アルゴン雲囲気，常圧焼 成で得たもっとも彩度が小さい焼結体の CIE 色度 $(X, Y)$ 図
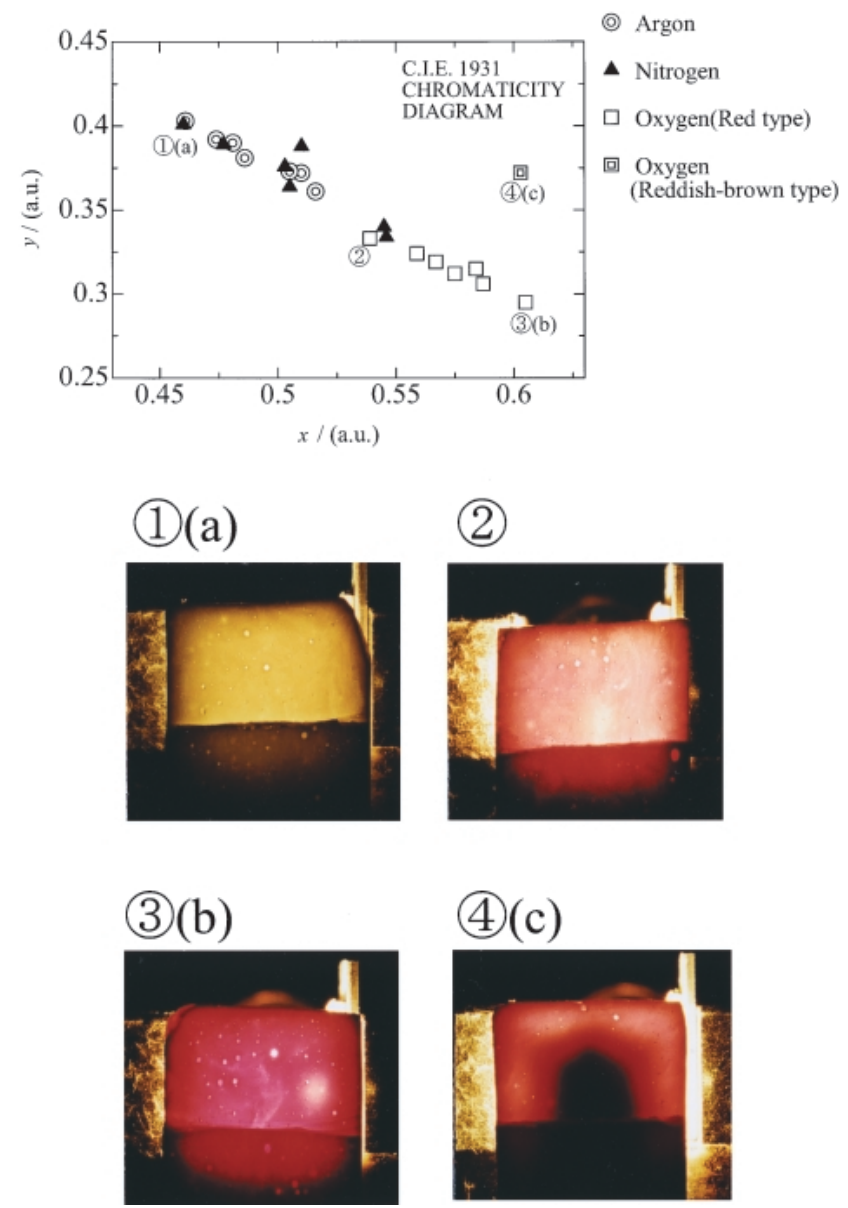

Fig. 1. Coloring of HAp blocks sintered in argon, nitrogen and oxygen atmosphere as shown on the chromaticity diagram.

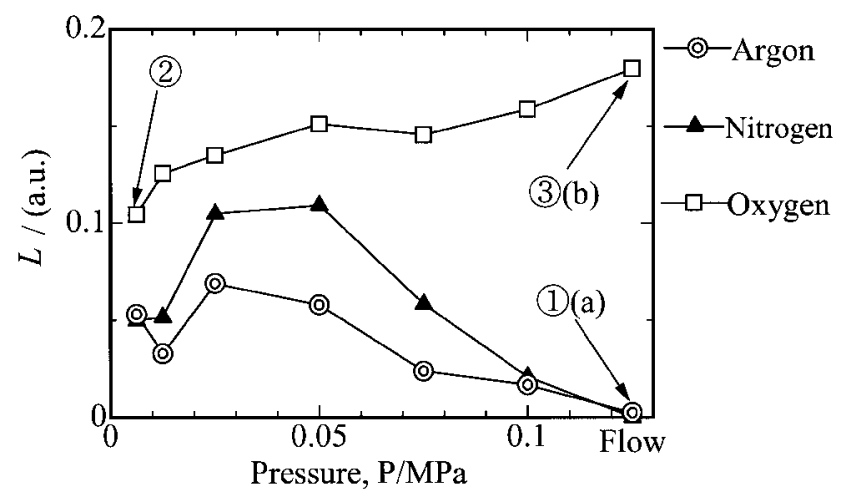

Fig. 2. Relationship between $L$ and pressure of furnace chamber at room temperature.

上の值 $(0.460,0.401)$ から, 各試料の CIE 色度 $(X, Y)$ 図上 の値 $(X, Y)$ までの長さ $L$ を(2)式により計算した。

$$
L=\left\{(X-0.460)^{2}+(Y-0.401)^{2}\right\}^{1 / 2}
$$

$L$ の値が大きいほど, HAp 焼結体がより強く着色しているこ とを示している. 図 2 は, 炉内の雾囲気ガス圧力 (常温での值) と焼結体の $L$ との関係を示したものである. 図中の(1)～(3)は図 1 の同じ番号の写真に対応している. 
図 2 から二つのことが分かる。第一は, 酸素の影響である. 酸素雾囲気中では，すべての圧力に拀いて焼結体が着色し， $L$ の值は 0.1 以上である. また, 圧力が増し炉内の酸素量が増え ると $L$ の值が大きくなっている，このことから，酸素が着色に 強く影響していることが分かる. 第二は, 圧力の影響である. 雾囲気をアルゴン, 窒素にした場合でも, 焼成時の圧力によっ ては着色現象を起こすことが，図 2 から見て取れる。 L は最初 上昇し, アルゴンでは $0.025 \mathrm{MPa}$, 窒素で $0.050 \mathrm{MPa}$ のとき最 大值となり, それ以上の圧力では小さくなった，一方，酸素雾 囲気の場合も, $L$ は $0.006 \mathrm{MPa}$ 以上の圧力で増加し, 0.075 $\mathrm{MPa}$ 付近でわずかに減少した。このように $0.075 \mathrm{MPa}$ 以下の 圧力下での $L$ の圧力依存性の振る舞いは三種類のガスについて 定性的に同じであることが分かる.このことから HAp の着色 には, 燒成時の雾囲気ガスの圧力が関係し, 常温時の圧力が $0.050 \mathrm{MPa}$ 付近のときに着色しやすいことが分かる.

次に，一度焼結した試料を二種類の䨌囲気ガス（酸素, アル ゴン）で再焼成した場合の着色変化について述べる. 酸素雾囲 気で焼成した赤色焼結体をアルゴン雾囲気で再焼成を行うと白 色焼結体になった，逆に白色焼結体を酸素雾囲気で再焼成する と赤色焼結体になった。 この可逆性は白色焼結体と小豆色燒結 体，赤色焼結体と小豆色燒結体間でも同様に起こった．HAp 焼結体の着色は最終焼成時の雲囲気ガスの条件によって決まる ことが分かる.

\section{2 着色 HAp のキャラクタリゼーションと発生原因}

図 3 は各着色焼結体とち密体の粉末 XRD パターンである. 全体図で見られるXRD パターンはすべて HAp に起因するも のであるが，拡大した図を見ると，白色焼結体(a) と赤色焼結 体(b)のXRD パターンには, JCPDS カードに示されるピーク 以外に図中の $\nabla \nabla$ で示す小さなピークが存在した. 特に, $\nabla$ の $2 \theta=36.26^{\circ}$ のピークはもっとも再現性良く観測された，一方， 小豆色焼結体 (c) とち密体 (d)の XRD パターンには, これらの ピークは観測されなかった. 図 4 は各着色焼結体とち密体の FT-IR 吸収曲線である. 白色焼結体 (a) と赤色焼結体 (b) の吸収 曲線と小豆色焼結体 (c) とち密体 (d)の吸収曲線を比べると, 前 者では $3572 \mathrm{~cm}^{-1}$ の $\mathrm{OH}$ 基の吸收 ${ }^{3), 6)}$ が大きくシャープであっ た。また $632 \mathrm{~cm}^{-1}$ の $\mathrm{OH}$ 基の吸收 ${ }^{3), 6)} 3572 \mathrm{~cm}^{-1}$ ほど明らか ではないが同様の傾向を示した. 一方, 白色焼結体 (a) と赤色 焼結体 (b)の FT-IR 吸収曲線には, 小豆色焼結体 (c) とち密体 (d)の吸収曲線に存在する $433 \mathrm{~cm}^{-1}$ のピークが見られなかった.

以上に示した XRD 測定と FT-IR 測定の結果から，着色した HAp は白色焼結体 (a) と赤色焼結体 (b)のグループと, 小豆色 焼結体 $(\mathrm{c})$ とち密体 $(\mathrm{d})$ のグループに分けられると考えられる.

HAp は単斜晶系と六方晶系の二つの結晶構造 ${ }^{3)}$, 文をとること が知られている. XRD パターンに拈ける単斜晶系から六方晶 系への相転移は, 単斜晶系に存在する $2 \theta=35.7^{\circ} \sim 37^{\circ}$ の間にあ る三つの小さなピークが，六方晶系では消滅していくことが Suda らによって示されている7). 図 3 の $\left(2 \theta=36.26^{\circ}\right)$ のピー クは,この三つのピークのうちもっとも強度が強いものと良く 一致している. 更に, 粉末 XRD 測定結果から $a$ 軸と $c$ 軸の格 子常数を求めた. 表 2 は, その結果である. 表に示すように白 色焼結体 $(\mathrm{a})$ と赤色焼結体 $(\mathrm{b})$ は $a$ 軸, $c$ 軸共に長く, 小豆色焼 結体 (c) とち密体 (d) は短かった. これと, 表 2 に示した Elliott と Young による単結晶の測定值 ${ }^{8)}$ と比較すると, 前者が単斜晶 系の結晶と後者が六方晶系の結晶と一致する. 以上の結果か ら, 白色焼結体と赤色焼結体のグループと, 小豆色焼結体とち 密体のグループの間に結晶構造の違いが見られ, 白色焼結体と 赤色焼結体が単斜晶系で, 小豆色焼結体とち密体が六方晶系の
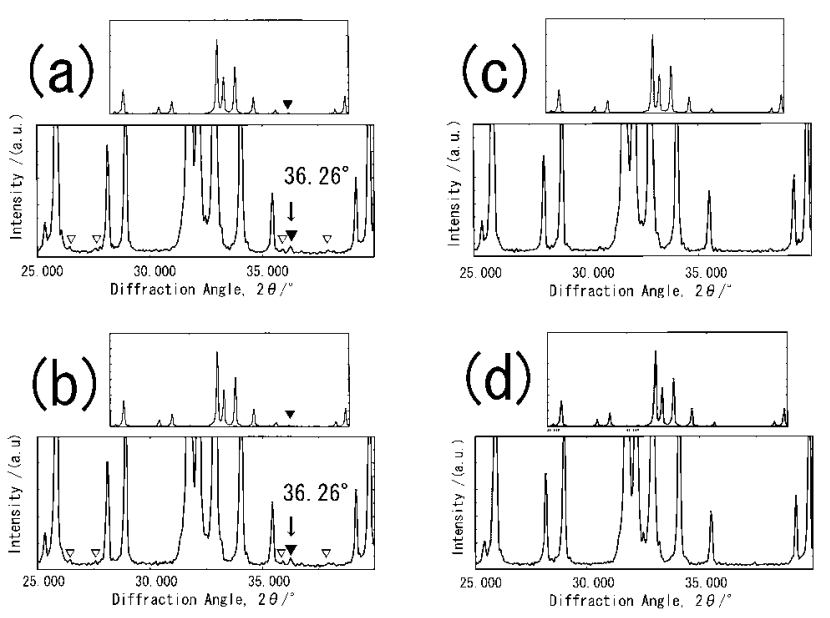

Fig. 3. X-ray powder diffraction patterns of HAp with (a) white type, (b) red type, (c) reddish-brown type and (d) high density type. $\nabla$ unknown small peak.
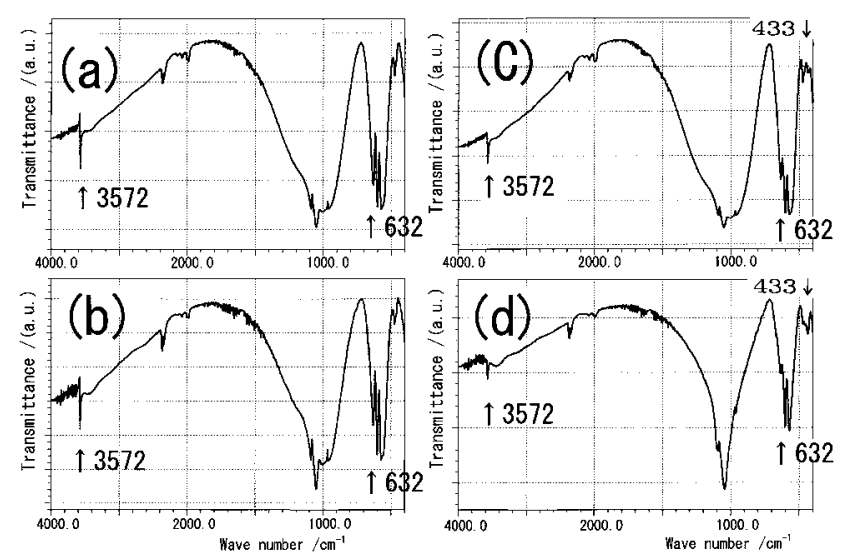

Fig. 4. FT-IR patterns of HAp (a) white type, (b) red type, (c) reddish-brown type and (d) high density type.

Table 2. Lattice Parameters of Coloring HAp Blocks and High Density HAp Sintered Block

\begin{tabular}{|c|c|c|}
\hline \multirow[b]{2}{*}{ Sample } & \multicolumn{2}{|c|}{ Lattice parameters } \\
\hline & a $/ \mathrm{nm}$ & $r / \mathrm{nm}$ \\
\hline $\begin{array}{l}\text { Monoelinic } \\
(\text { Singlo crystal) }\end{array}$ & 0.9422 & 0.6883 \\
\hline $\begin{array}{l}\text { Llexagonal } \\
(\text { Single erystal) }\end{array}$ & 0.940 & 0.686 \\
\hline White type (a) & 0.9421 & 0.6882 \\
\hline Red lype (h) & 0.9421 & 0.6882 \\
\hline Reddish-brown lypo (c) & 0.9404 & 0.6872 \\
\hline High density type (d) & 0.9411 & 0.6874 \\
\hline
\end{tabular}

結晶からできていると考えられる. 更に, これらの着色現象が HAp 焼成時の雾囲気により制御できることから, HAp は焼成 時の雾囲気制御により, 可逆的に相転移することが分かる. 次 


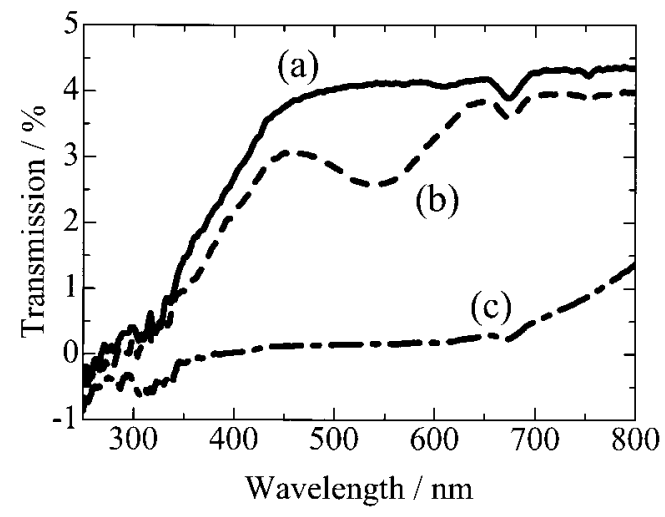

Fig. 5. Transmission curves of HAp with (a) white type, (b) red type and (c) reddish-brown type.

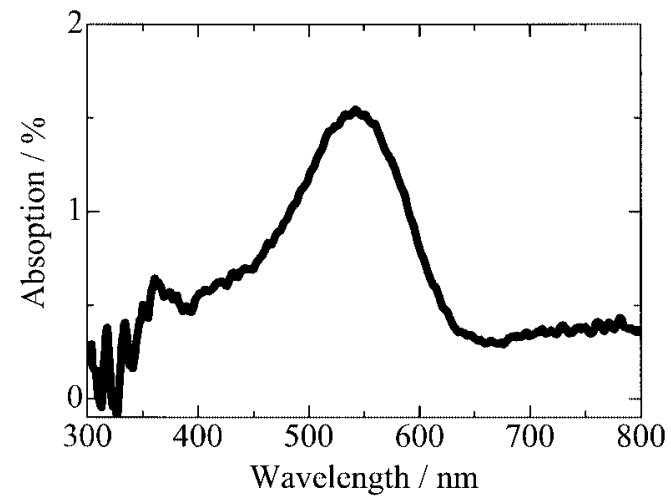

Fig. 6. Absorption band of red HAp block (red type).

\section{に，赤色焼結体の発生原因について検討する.}

図 5 は各着色焼結体の分光透過率の測定結果である. 白色焼 結体 (a)の透過率は可視光域全体に高く, この試料の CIE 色度 $(X, Y)$ 図上の座標值と対応している. 赤色焼結体 (b) は, 537 $\mathrm{nm}$ 付近に吸収帯が存在した. 小豆色焼結体 (c) は可視光域全体 に透過率が低かった。これは, 図 1(4)(c)の写真に対応する. 図 6 は白色焼結体の透過率から赤色焼結体の透過率の值を引き 赤色焼結体の吸収帯を示した図である。この図より赤色焼結体 には, 色中心と思われる $537 \mathrm{~nm}$ を中心とする吸収帯が存在す ることが確認できた。

図 7 は ESR 測定結果である. 小豆色焼結体 (c)の試料では, $g=2.0056$ の信号が確認されたが, 赤色焼結体 (b)では信号が確 認されなかった。二つの試料がほぼ同じ大きさであることを考 慮すると赤色焼結体には不対電子が存在しないか有ってもごく 少数であると考えられる．データは示していないが，白色焼結 体の試料からも信号は得られなかった．赤色焼結体の着色発生 原因を検討すると，1)この着色現象が，2 価のイオンになりう る酸素雾囲気中での焼成によって引き起こされること，2) 537 $\mathrm{nm}$ の吸收帯が存在すること, 3)不対電子が存在しないことか

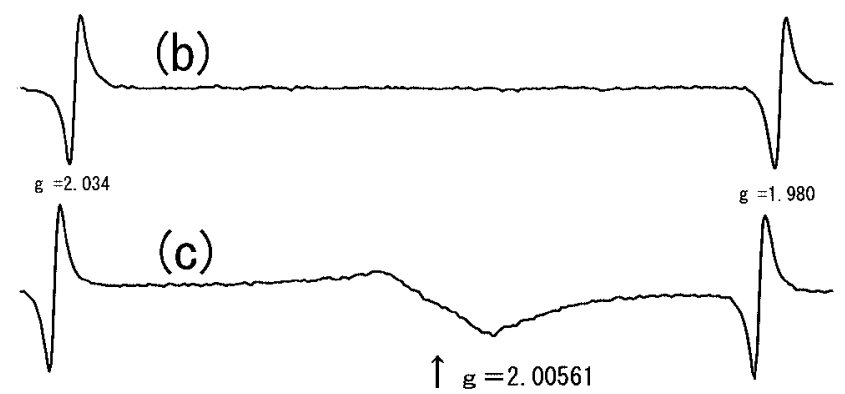

Fig. 7. ESR signals of HAp (b) red type and (c) reddish-brown type.

ら，酸素がHApに何らかの形で吸着し，それを起点にしてで きた 2 価の色中心によるものであると考えられる.

\section{4. 結 論}

（1） HAp 焼結体が焼成により赤色焼結体，小豆色焼結体に なる二種類の着色現象は, 酸素によって引き起こされている.

（2）小豆色焼結体は，XRD パターンの特徵と格子定数の測 定よりち密体と同じ六方晶系であり, 白色・赤色両焼結体は, 単斜晶系である.

（3）赤色焼結体の着色発生原因は, 酸素による 2 価の色中 心であると考えられる.

以上のようなことが分かったが，酸素が着色の起点になって いるならば，HAp 中に酸素が含まれているはずである. 今後 は酸素とHAp の関係について検討を行うとともに, 窒素, ア ルゴン雾囲気で減圧時, わずかに着色する現象, 小豆色焼結体 とち密体が同じ結晶構造でありながら, 光をほとんど通さない 小豆色と乳白色になるのかなどの検討が必要である.

謝辞 本研究を進めるに当たり多くの助言を頂いた，法政大 学·守吉佑介教授, 工学院大学・門間英毅教授, 東邦大学・梶田晃 示教授, ペンタックス株式会社ニューセラミックス事業部インキュ ベーションセンター・日高恒夫ペンタックスフェローの皆様に感謝 します。

\section{References}

1) Hirano, M., Kinzoku, Vol. 68, pp. 23-30 (1998) [in Japanese]. 2) Koukai Tokkyo Kouhou, Showa 55-130854 (1980).

3) Aoki, H., “Apataito," Ishiyakusyuppansha (1999) [in Japanese].

4) Moriwaki, Y. and Suga, S., "Ha," Kyoritsu Shuppan (1981) pp. 72-91 [in Japanese].

5) Ishikawa, T. and Ogawa, T., J. Ceram. Soc. Japan, Vol. 112, pp. 57-60 (2004) [in Japanese].

6) Monma, H. and Takahashi, T., Gypsum \& Lime, No. 210, pp. 29-33 (1987) [in Japanese].

7) Suda, H., Yashima, M., Kakihana, M. and Yoshimura, M., J. Phys. Chem., Vol. 99, No. 17, pp. 6752-6754 (1995).

8) Elliott, J. C. and Young, R. A., Nature, No. 214, pp. 904-906 (1967). 